\title{
Museal stedsudvikling: Tordenskjold was here!
}

\author{
SARAH Holst KJeR*
}

Title: Museal place development: Tordenskjold was here!

Abstract: Regional museums are shifting their focus away from collections and are involving themselves in urban planning, place design and place making. 'History' has become an identity brand which marks sights. During the last decade, museums have therefore engaged in a new role as cultural innovators. When transforming urbanity into experiencescapes, the museal competence regarding 'the local past' is recycled into geographies of recreational consumption. This article discusses a particular case of urban planning - the development of the Isegran tourist and recreational area in Fredrikstad, Norway. Here the town's city council included the local museum in defining a 'master plan' for cultural regeneration. Urban place making took its point of departure in the town's maritime history.

Key words: Cultural planning, experience design, community design, aestheticisation, storytelling, maritime heritage, ordinary things.

Rekreation, kulturoplevelse og fritidskonsumption var i perioden omkring år 2000 netop de ingredienser en by burde indeholde. Oplevelsessamfundet var også blevet lokalmuseets nye projekt. Denne artikel diskuterer museet som central aktør for en bys omdømme og identitet, hvor publikum er blevet kundesegmenter, og hvor dannelse er blevet til oplevelsesprodukter. Artiklen handler også om, hvordan turisme og oplevelseskonsumption forventes både at udspringe af kulturhistorie og fortidsminder, samt leve op til kommunale og regionale visioner om økonomisk bærekraft, vækst og succes.

Artiklen handler om, hvordan museal steds- udvikling forhandler museale idealer i byplanlægningens kommercielle, populariserende og oplevelsesbaserede strategier. Feltarbejdet er baseret på observation, interviews og fotografering på Isegran, i Gamlebyen og på Østfoldmuseene (Fredrikstad Museums bymuseale udstilling og Gamlebyen som helhed) i Norge. Desuden er turistbrochurer undersøgt, og interviews med museets, kommunens, og turistburauets ansatte er foretaget. Artiklens analyse er primært forankret i styringsdokumentet Business to Heritage (2010), udarbejdet af Fredrikstad Kommune, samt præsentationen IKON. Fredrikstad i 1700-tallet (Normann 2011), udarbejdet af Østfoldforskning. Også 


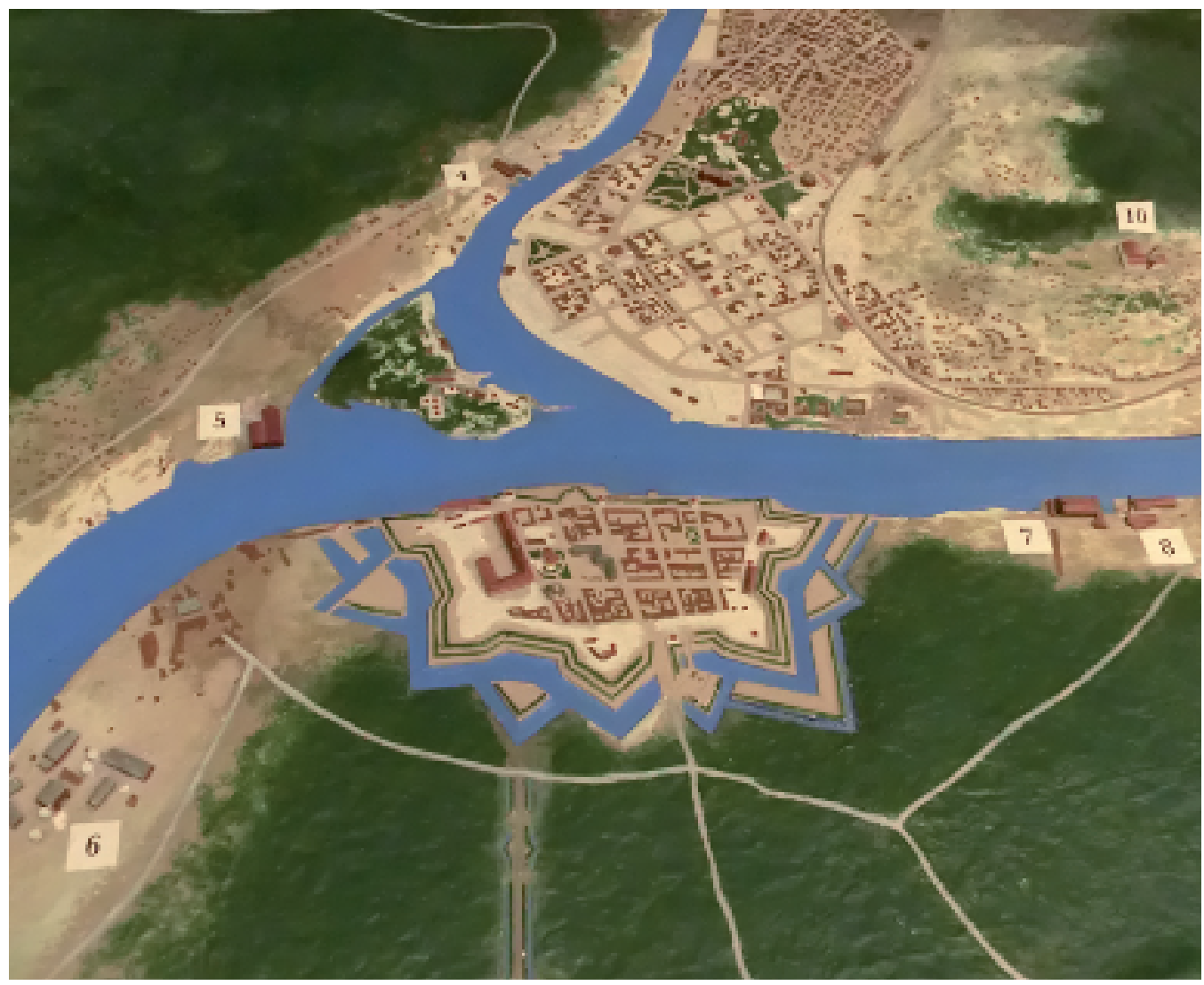

Fig. 1. Isegran ø. Museumsmodel, ukendt år. Fredrikstad Museum. Foto: Sarah Holst Kjar, 2012.

skriftet fra Oslo Universitets Arkeologiske Stasjon Isegran De annalibus Isegrani. Hendt på Isegran 1287-1997 (Johansen 1999) anvendes.

Artiklen afspejler konsulentbranchens sædvanlige opgaveform, som går under navne som business anthropology, corporate storytelling eller custommade ethnography. Kulturforskere, som jeg, arbejder mere og mere som kundskabsentreprenører bestilt af kulturindustri og kulturadministratorer.

\section{REGENERERING}

"Var Tordenskjold her?" Efter længere tids bilkørsel ad forkerte GPS-ruter var jeg endelig ankommet til Fredrikstad i Norge. På øen Isegran skulle jeg i feltarbejde og vurdere en stedsudviklingsopgave for kommunen og museet. En hengemt sted midt i Vesterelva skulle blive en bydel, baseret på stedets kulturhistorie (se fig. 1). Målet var at forlænge turisternes 


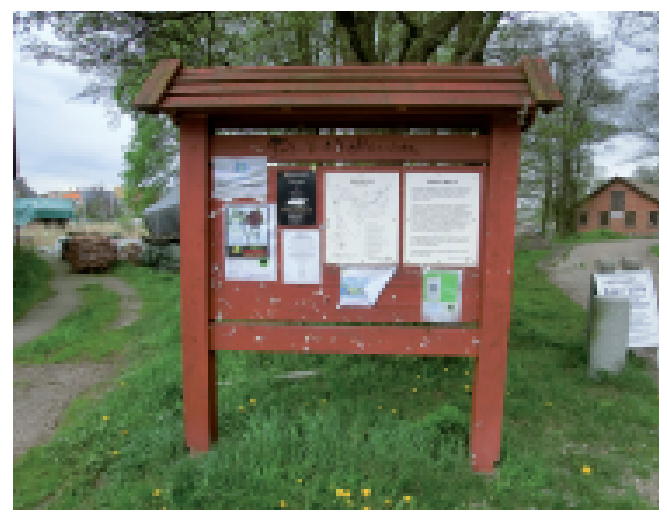

Fig. 2. Indgangen til Isegran. Foto: Sarah Holst Kjer, 2012. ophold, når de alligevel besøgte den norske fæstningsby, men også at skabe et nyt byrum for borgerne.

I takt med at arbejdspladserne - primært universitetets marine-arkæologiske afdeling var blevet nedlagt på øen, havde den lokale bådebus sløjfet Isegran på sin rute. Nu fungerede Isegran mest som hundeluftningsplads for naboerne, søspejderne kom en gang om ugen, enkelte børnehaver havde også set den grønne $\varnothing$ som en mulighed for frisk luft i byen (se fig. 2). Et enkelt kommercielt bådværft havde sine daglige arbejdsrutiner i den ene ende af øen (se fig. 3). Ligesom andre byområ-

Fig. 3. Bådebyggeri i brug. Foto: Sarah Holst Kjar, 2012.

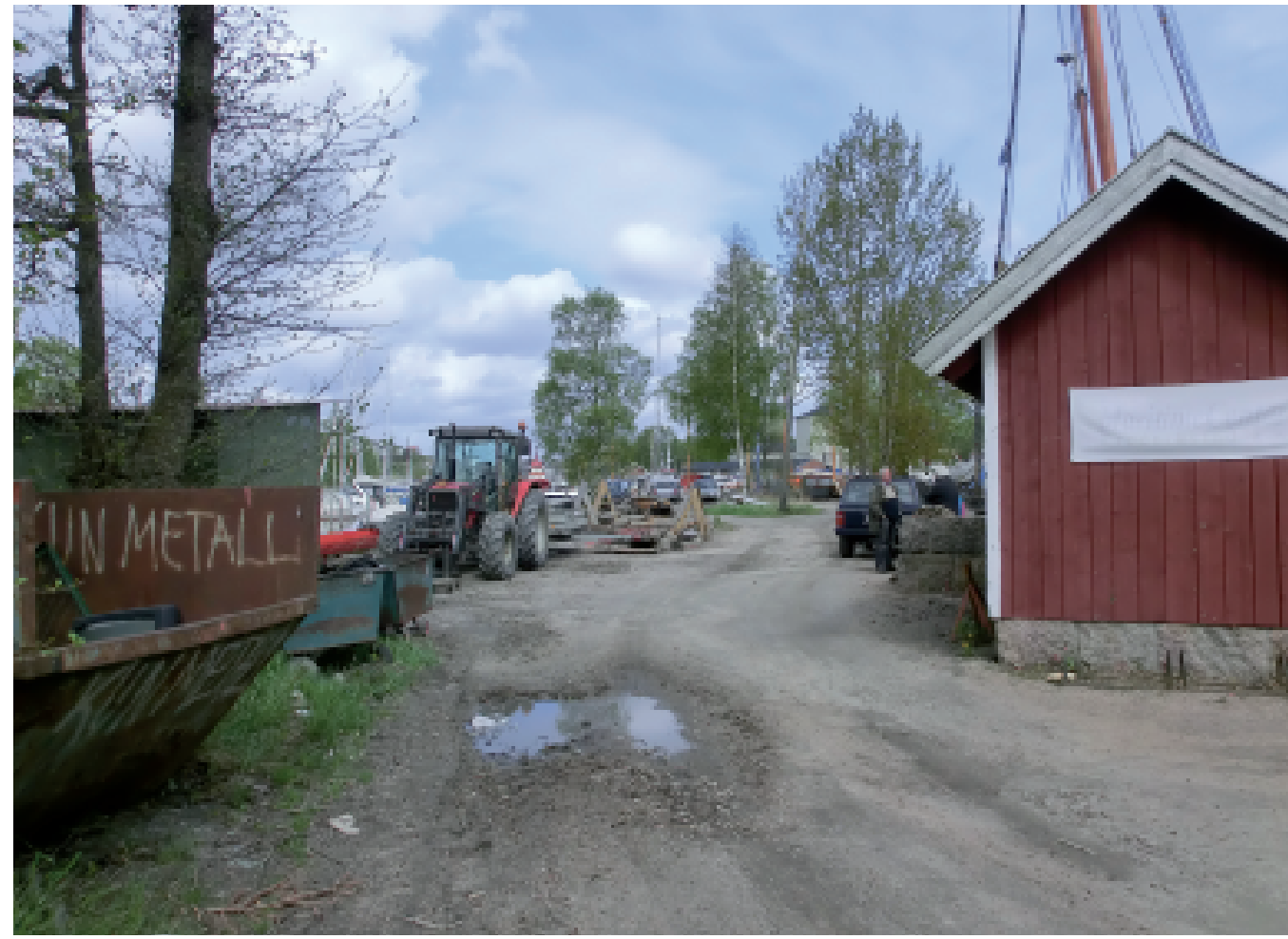




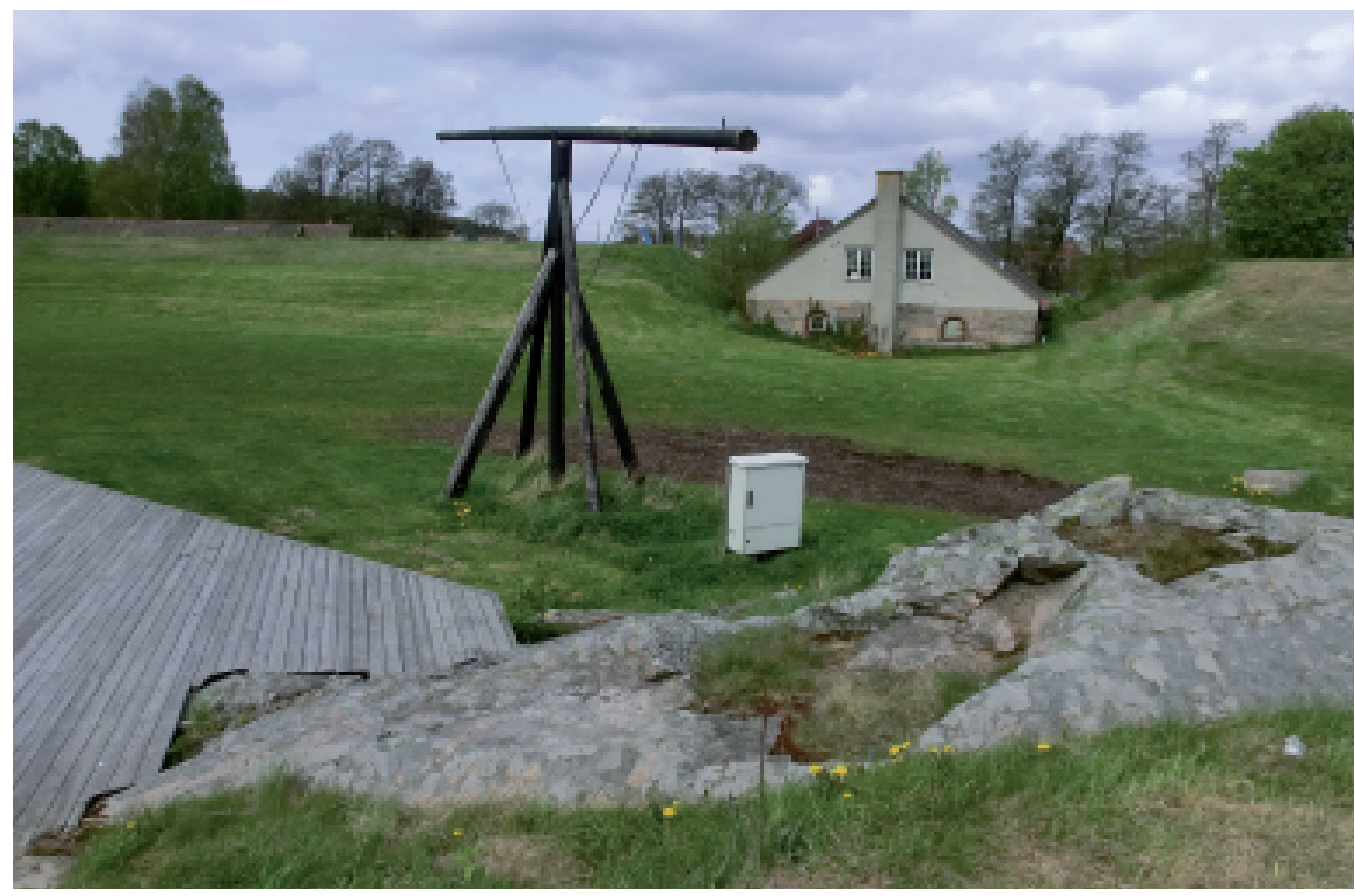

Fig. 4. Amfi-scene på Isegran. Foto: Sarah Holst Kjar, 2012.

der bar Isegran præg af sin lange og varierede historie med forskellige byggestile: Små træhuse lå spredt, en enkelt lille borgruin var udråbt til kulturarv, men ved at styrte sammen, et par gamle vandmøller og et moderne kommunalt byggeri, en amfi-scene, lå næsten stille (se fig. 4). Kun fiskerestauranten holdt trofast åbent året rundt og glædede sig til, at Fredrikstad bymuseum endelig skulle sætte sit maritime præg på øen og levendegøre den.

\section{Stedets GeneAlogI}

"Ja, søhelten Tordenskjold var her. Han erobrede den svenske flådes vigtige forsyningsfartøjer i slaget ved Dynekilen i 1716, hvilket blev hovedårsagen til at den svenske konge,
Karl d. XII, opgav sit forsøg på at erobre Norge i Den Store Nordiske Krig", forklarede museets maritime udviklingskonsulent, mens han pegede ud af fiskerestaurantens vindue. "Forsyningsfartøjerne - fire eller fem - slæbte Tordenskjold her til Isegran. Det var hans pris, tyvekoster eller krigsbytte - hvad man nu vil. Vraget efter et af skibene findes endnu ved indløbet til Nøkledybet fra Vesterelva”, forklarede han (se også Johansen et al 1999: 8-9). Men ikke nok med det, fortsatte han: "for nogle år tilbage, bjergede Fredrikstad Museum faktisk et af Isegrans sunkne krigsbytter fra Tordenskjolds togt i 1716. Skibet var i en periode klodset op i Gamlebyen. Det gik i brand, fordi nogen holdt sommerfest på vraget og bagte kartofler i den knækkede mast". "Det 


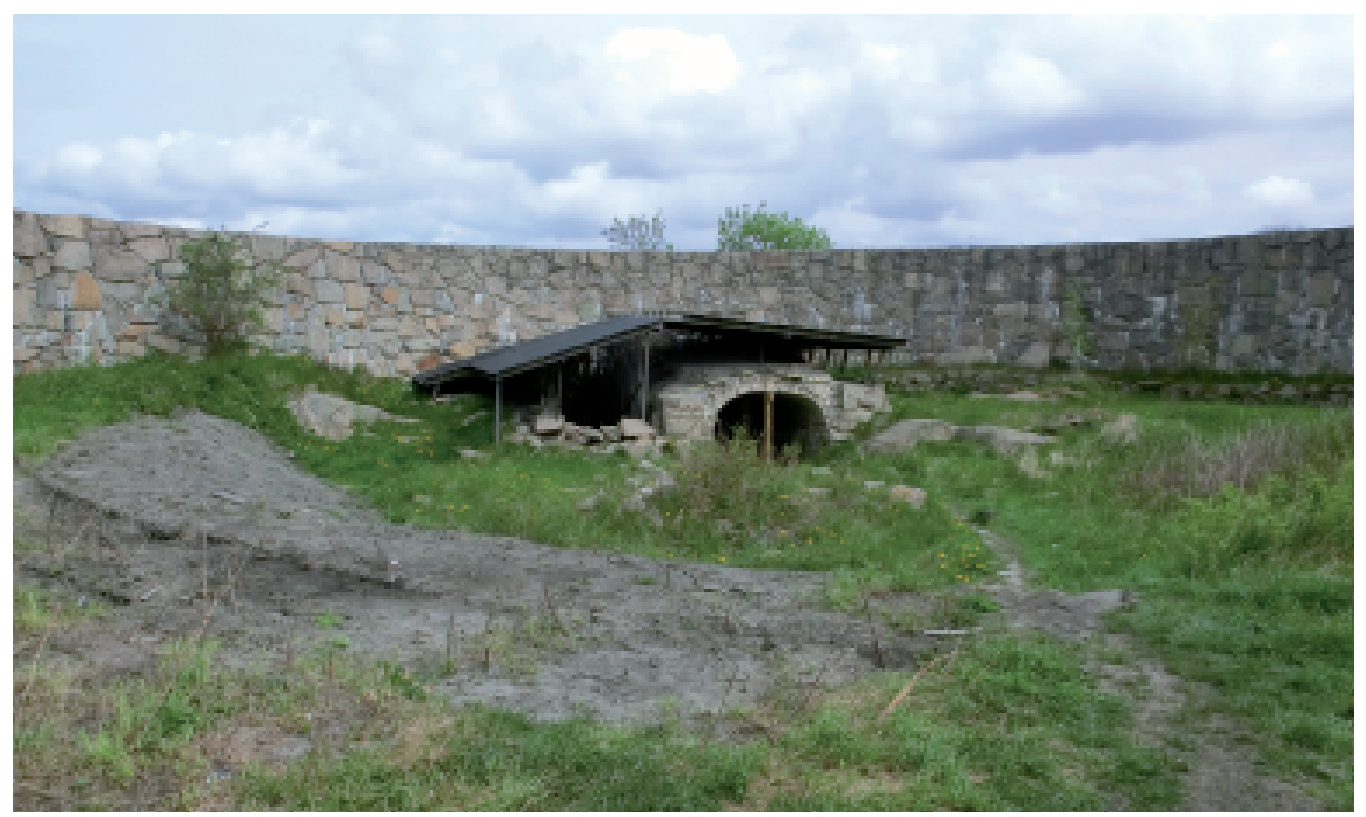

Fig. 5. Tårnet. Borgruinen på Isegran. Foto: Sarah Holst Kjer, 2012.

lyder som en god historie. Bruger i den?", spurgte jeg og var i færd med at gøre genstandene - også de imaginære - til fortællende ting. Det gjorde man ikke.

Peter Wessel Tordenskjold (1690-1720) kom ikke fra Fredrikstad, men fra Trondheim. I øvrigt havde han været snart sagt alle steder i sin karriere som søhelt. Det virkede ikke indlysende at gøre krav på hans historie. I stedet var det fortællingen om 1200-tallets vikingejarl Alv Erlingsson den yngre der fremhævedes som grundlægger af Fredrikstad. Selvom han døde i Helsingborg i 1290, og man ikke vidste, hvor og hvornår han blev født, opfattedes han alligevel som mere oprindelig og forankret. Dette var særligt begrundet i Erlingsson den yngres mindre træborg. Den mentes at have været dér hvor resterne af øens nuværende stenruin - Tårnet - lå (se fig. 5). Den bag- vedliggende orden, som begrundede dette valg, handlede om at skabe en historicistisk genealogi - at begynde fra begyndelsen eller $\mathrm{i}$ al fald begynde med den begyndelse, man med nogen sansynlighed havde genstande til. Tingen - stenruinen - havde således den mening og funktion, at den blev opfattet som identisk med det projekt at skabe en stedsidentitet, som kunne dateres så langt tilbage som muligt. Dette genealogiske synteseprincip bortrensede naturligvis - og det var hensigten det, man anså for ligegyldige eller uforankrede ordener (von Plessen 1993: 72-74).

Museets maritime udviklingskonsulent skulle lede de fremtidige etableringsprocesser sammen med chefen for kommunens Kultur- og næringsafdeling.

Over frokosten blev der snakket om i hvilken retning man burde gå. Der skulle skabes 
museale fortællinger, men på hvilket grundlag? Museets udstillinger, samlinger og fortællegreb skulle fungere som et kulturbaseret oplevelsesdesign af øen.

\section{STEDSUDVIKLING}

En lokal kultursektor har sommetider ringe kundskab om det oplevelsesmarked, samt de turistiske og konsumptionsbaserede tendenser, man ønsker at udfordre. Det museale oplevelsesdesign og øens oplevelsesgeografi skulle placeres i en urban revitaliseringspraksis, hvor de museologiske, kommunale, kommercielle og ideelle perspektiver tilsammen skulle blive et udgangspunkt for byrummets udvikling.

På øen Isegran ønskede Fredrikstad kommune sig byudvikling, stedsidentitet, kulturarvsturisme og museumsteablering på en gang. Cultural planning kan måske indkredse kommunens tilgang, hvor "kultur" opfattes både som dannelse og som måder at leve på. Cultural planning er en type byplanlægning, der handler om at genanvende lokale kulturgenstande, personligheder og fortællinger for at skabe æstetisk og tematisk identitet og særkende, samtidig med at de besøgendes og befolkningens behov for meningsskabelse og dannelse stimuleres. På den måde, mener man, er regional udvikling lykkedes (Evans 2001: 7).

Kulturel byplanlægning - stedsudvikling eller place making - handler således om at forbedre et sted, gøre det mere produktivt, lønsomt og attraktivt ved at tilbyde identitetsmæssige kvaliteter i fritidsoplevelser, pladsdesign og tematisk udforming, således at mennesker synes det både er værd og meningsfuldt at opholde sig der (Thufvesson 2009).

Rent partnerskabsmæssigt var det klogt at inddrage museet lige fra begyndelsen - dette var nu givet i de EU - finansierede interregionale projekter man deltog i, men for en kommune er det ikke usædvanligt at lade kommunikations-, markedsførings- eller brandingfirmaer, som arbejder med community design eller destinationsdesign, producere nøgleord, oneliners og slogans, for, på den måde, at opbygge en stedsidentitet (Strömberg 2009: 14). Sådanne firmaer har som oftest en mindre forståelse for det, som er lokalmuseets ekspertområde. Med dets historiske rolle som dannelses- og oplysningsproducent i nationalstatsprojektet er den stedsbaserede fortælling museets spidskompetence (Kayser Nielsen 2009). Som udstillingskurator må "man [...] på en måde vide, hvad det er, man leder efter", forklarer den tyske museolog Marie-Louise von Plessen: museologen er trænet i primærkildedokumentation, men også i fortællestruktur (von Plessen 1993: 128). Museets årelange erfaring med symbolsk og materiel identitet kunne således anvendes til revitalisering af geografier, sådan som oplevelsesøkonomien ved årtusindeskiftet foreskrev det (Aronsson, Bjälesjö \& Johansson 2007).

Øen Isegran var præget af forskellig materialitet. Den havde undergået en række udviklingsprocesser - fra militærfestning, vanddrevet industri, garnisonkirkegård til museum og marine-arkæologisk forskningsvirksomhed. Bygningsmassen var derfor meget varieret, men også relativt sparsom. Øen som helhed bar præg af grønne områder med græsplæner, tilfældig urbanisering, dvs. stor variation i stilarter - bådevæft som stadig var i brug, borgruinen Tårnet, Det gule hus med Isegran-hagen - en urtehave i renæssancestil, træbygninger og murede bygninger, samt det relativt nyopførte amfi-teater som kunne rumme ca. 2000 siddende og 5000 stående publikummer. 
70 Øens nye stedsdvikling skulle anlægges med musemsudstillinger, oplevelsesaktiviteter, hotel- og servicekonsumption. Der skulle også være fritidsområder, måske en eller flere strande, samt hvile-, lege-, motions- og rekreationfaciliteter.

\section{KULTUR SOM ADDED VALUE}

Isegrans stedsudviklingsform var del af en vestlig, urban tendens, hvor fritids- og oplevelsessamfundet skulle overtage den gamle industriby (Kjær 2010). I tiden omkring årtusindeskiftet markedsførte byer, regioner og hele nationer over hele Europa sig med henvisning til deres "unikke karakter". Men de fulgte også et veletableret mønster, nemlig at de fleste fremhævede den lokale kulturhistorie og kulturarv. Der var et overnationalt, nationalt og lokalpolitisk ønske om at anvende lokalmuseerne som indholdsleverandører til nye oplevelsesprodukter. Kultur skulle helst have en nyttefunktion - være lærerrig, identitetsskabende, kommercialiserbar og helsebringende. Historien måtte materialiseres, blive et oplevelsesprodukt og en spændende shoppingmulighed. Den rette balance mellem urban puls og sundhedsskabende fritidsliv, forvandlede kulturarv til oplevelsesøkonomi: Når byen markedsførte sig selv - i placebrands og turistbrochurer - handlede det om at sælge og produktificere fysiske landskaber, pladser og rum, men det handlede også om hele tiden at udfordre forholdet mellem fantasi og materialet, historien og den gode historie (O'Dell 2002: 22, 26, 28).

Fredrikstad by var en del af denne oplevelsesøkonomiske trend. Kommunen ville anvende museets ressourcer - fortællinger, genstande og kundskab - som oplevelsestilbud i bylandskabet. Målet var at markedsføre, ople- velsesdesigne og skabe added value - ekstra værdi for byen, turister og borgere (Kjær 2011a). Museerne var kommet til at række ud over sig selv og var blevet en strategisk samfundsaktør for urban identitet og udvikling.

Som kulturhistorisk institution var museets formålsparagraf at samle, registrere, opbevare, udstille og formidle en given kulturarv (Nielsen 1993: 5). Nu skulle museet imidlertid få en central rolle som stedsudvikler og oplevelsesdesigner. Ved interviewene forestillede museets ansatte sig, at dette rolleskift ville være en spændende forandring, men projektet var så ungt, at arbejdsopgaverne endnu ikke var defineret. I kulturhistorisk perspektiv er museologisk stedsudvikling imidlertid ikke er nyt eller usædvanligt. Et tidligt eksempel er den engelske samler Sir John Soane som i 1700-tallet stiftede et encyklopædisk museum med alt fra pompejanske oldtidssager, rejseminder, græske krigsbytter og akitekturtegninger fra renæssancen. Da han i 1788 blev udnævnt til arkitekt for Bank of England, benyttede han sin genstandsmæssigt åndelige udrustning som urbanist og forskønner af London. Sir John Soanes mytologiske samling blev på den måde virkeliggjort (efter von Plessen 1993: 130).

\section{KULTURARV OG KOMMERCIALISME}

Turisme- og fritidskultur, museets dannelsestilbud og kommunens stedsidentitet skulle fusioneres i et samlet oplevelsesdesign for Isegran. Ved feltarbejdet i 2012 forelå den kommunalt formulerede projektbeskrivelse Business to Heritage (2010), som det officielle styringsredskab for Isegrans stedsudvikling.

Projektbeskrivelsen blandede kulturarv med kommercialisme. I fremtiden skulle "attraktive og kunnskapsbaserte opplevelser [...] skape flere besøkende til regionens kulturelle 
og historiske reisemål [...]. Plassens kjerneverdier skal utvikles gjennom historiefortelling, delaktighet og prioriteringsgrunner". Man ønskede at skabe fundament for "fungerende samarbeidsrelasjoner, forretningsplaner, finansiering, kompetanse, tilvekst av næringsdrivende innen kulturell, kreativ og turismerelatert næring”. En "langsiktig økonomisk bærekraftig destinasjon med kulturarven i fokus" skulle Isegran blive.

Desuden var primærmålgrupperne næringsaktører, "eksisterende og nye, samt unge entreprenører"; interessenterne: "det offentlige, frivillige (særlig unge pensjonister), destinasjonsselskaber og reiselivsnæring, samt investorer/sponsorer". Publikum forklaredes som "un- ge barnefamilier, konferansemarkedet, samt maritimt interesserte (historie, håndverk, båt)" .

Fredrikstad museums maritime afdeling skulle ligge på Isegran. Kulturarven var defineret som "maritim" - deraf interessen for søhelten Tordenskjold og vikingejarlen Erlingsson den yngre og deres bedrifter. "Det maritime" betyder egentlig blot "det, som omhandler havet" og kan som bekendt være alt fra shippingaktivitet, måger, sejlbådsinteriør, gummistøvler, sydvest, fiskeri, vikingetid, Tall Ship Race, og carribiske eller somaliske pirater. Det kan også være norske kapere eller boreplatforme til havs. Det maritime kan desuden omhandle alt fra havudsigt, jordomsejlinger, strandvegetation, marinebiologi eller bådbyg-

Fig. 6. Planer om en fremtidig museumshavn på Isegran. Foto: Sarah Holst Kjer, 2012.

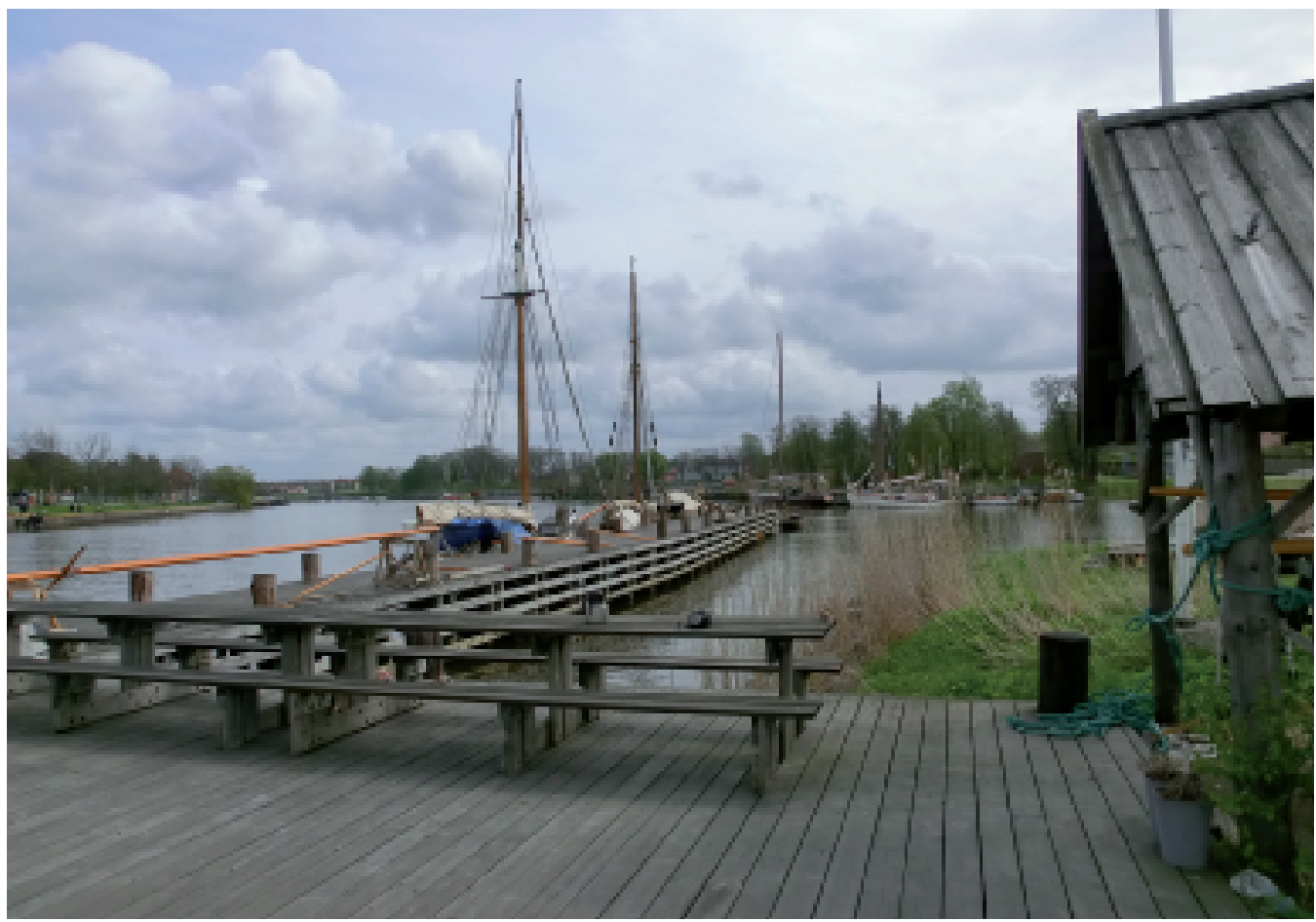


72 geri. På Isegran var det maritime en forudsætning, som skulle tematisere en fremtidig museumshavn, men også hele øen og alle dens aktiviteter (se fig. 6).

"Historiefortellingen" blev af museet antaget for at være knyttet særligt til Alv Erlingsson den yngre og til øens ældste bygning, nemlig ruin-Tårnet. Det er således ikke ualmindeligt, at "kulturarv" defineres som bevaringsværdige materielle genstande og bygninger, som står $\mathrm{i}$ fare for at forsvinde og gå tabt (Ronström 2007: 196-197). Imidlertid har man i de senere år fokuseret på kulturarv som mere end genstande og bygninger. Kulturarv er i ligeså høj grad immaterielle fænomener, såsom håndværk, fortællinger og traditioner. Sidstnævnte kulturarvsdefinition passer godt til lokalmuseets rolle som kundskabsbaseret stedsudvikler. Med den immaterielle kulturarv kan man gestalte, sandsynliggøre og symbolisere fortiden, samt gøre den relevant i nutiden med levendegørelse, iscensættelse og begivenheder (Aronsson 2004: 143-182).

På Isegran kunne man fokusere på mange af de bevarede materialiteter - vandmøllerne, renæssance-haven eller den nedlagte marine-arkæologiske stationen. Alle områder og genstande var fredede eller bevaringsværdige. Den sammensunkne borgruin, Tårnet som vikingejarlen Erlingsson den yngre efter sigende havde beboet, var udråbt til kulturarv. Ville man, i 2012, imidlertid vide noget om Tårnet og Erlingsson den yngre, fik man blot 2120 træf med Googles søgemotor. Til sammenligning fik Peter Wessel Tordenskjold et resultat på 724000 træf.

Fra museets side ønskede man at planlægge og udvikle området med empirisk dokumentation af det forgangne og en genealogisk historieskrivning. Kommunen ønskede derimod en popularisering, kapitalisering og demokrati- sering af kulturhistorien. Fortidsbrugen skulle anvendes strategisk for at gøre byens identitet meningsfuld i samtiden (Eriksen 2002; Kayser Nielsen 2009).

Med museets nye rolle som steds- og oplevelsesproducent, og for at imødekomme kommunens nytteperspektiv, fremstod det nødvendigt i projektet at beherske andre typer formidling end genstandsformidling og historievidenskab. Storytelling var et vigtigt begreb i denne sammenhæng. Når begrebet anvendes i stedsudvikling, handler det om at fortælle historier ud fra modtagerens perspektiv - hvem lytter, hvad genkendes, hvad er interessant?

Storytelling handler således om at markedsføre byen ved at appellere til udenforståendes loyalitet. Udvalgte dele af historien - følelsesladede vendepunkter snarere end information og fakta - anvendes. Fortællestilen minder om markedsføring som på kort tid kommunikerer en situation, et drama, en længsel, som borgere og gæster emotionelt - menneskeligt og eksistentielt - kan relatere til (Hjemdahl 2003: 115).

\section{Museologi Og MENING}

Tilbage til Isgrans fremtidige museumsø var "det maritime" en ud af flere mulige historier: det var en identitets- og idealfortælling, men det var også en kontekstbaseret orden og en æstetiseringsmetode, hvor det maritime skulle tematisere øens miljø og oplevelsesdesign. Den maritime natur forventedes at være nyttig og produktificerbar - søfart, sømad, søbad. "Det maritime" var en geografisk tilgang som kunne bringe genstande af vidt forskellig beskaffenhed og kvalitet sammen. Det var muligt at lave nye fortællinger med ting af den mest trivielle herkomst og måske tilføje enkel- 
te ærværdige kulturarvsgenstande. Det "forhåndenværende materiale" skulle anvendes til at designe og æstetisere øen, således at det lærings- og meningsmæssigt fremstod indlysende, at her var der tale om en større søkrigshistorie med en søhelt (von Plessen 1993: 128, Mordhorst 2009: 256-269). I interviews med de museumsansatte anså man vikingejarlen Alv Erlingsson den yngres historie som mest relevant, og under feltarbejdet på øen tronede rigtignok en buste af Erlingsson. Men Isegrans historie rummede også spor af andre betydningsfulde mænd - ingenørofficerer, øverstkommanderende, generalmajorer, oberster, kommandander, arkitekter, malere, strømmøllebyggere, professorer, statsstipendiater, parkchefer. Alle havde de præget øens udvikling (Johansen et al 1999). Isegran, som i mange år havde fungeret som fæstningsværk, var i sandhed en maskulinitetsfortælling over byens heroiske mænd som, over flere hundrede år, havde forsøgt at holde svenskere væk, tage imod kongelige og andre øvrighedspersoner fra indog udland, drive videnskab, passe kirkegård og holde urtehave. Alligevel blev Tårnet - borgruinen, symbolet på Fredrikstads skabelsesberetning. Perioden, hvor Erlingsson den yngre havde opholdt sig på øen, havde ganske vist varet et år, i 1284-1285, hans træborg var for længst gået tabt. Efter sigende have han hærget i Danmark og Sverige, inden han blev henrettet i Helsingborg (Johansen et al 1999: 4-5). Tårnet eksemplificerede (næsten) Norges stolthedstid, vikingetiden.

Meningsbegrebet er ikke nyt i kultur- og museumsverdenen. Også på Isegran var kundskab, læring, æstetik, orden og systematik eksempler på de meningsformer man efterstræbte. Isegran skulle også være et byrum, der fremstod som vigtigt og relevant for (næsten) alle byens borgere. Imidlertid er oplevelsen af mening bestemt af sociale, kulturelle, etniske og klassemæssige tilhørsforhold, forklarer kulturteoretikerne Stuart Hall and Paddy Whannel (1964: 66). Selvom udviklingsprojektet til at begynde med var et 'top-down' projekt, kunne museets rolle som stedsudvikler dog både blive socialpolitisk og ideologisk i den betydning, at museet med sit kulturelle og læringsmæssige stedsdesign skulle gøre byen harmonisk og spændende og derved reducere sociale konflikter og levendegøre et nedslidt område af byen.

\section{CutTing EDGE}

Isegrans signatur-fortælling - place brand eller metanarrativ - stod mellem de to søhelte Tordenskjold eller Erlingsson den yngre. Kommunens ambition var at byen fik et attraktivt omdømme og et meningsfuldt kulturliv. Med sit "helhetlige opplevelseskonsept" havde "arenaen ambitioner om å skape aktivitet og events med nasjonalt og internasjonalt nedslagsfelt", stod der i kommunens projektbeskrivelse Business to Heritage (2010). Også i kommunens bestillingsværk IKON. Fredrikstad i 1700-tallet kunne man læse, at Isegran skulle have "turistarrangører", "markedsføring" og "bookingsystemer" (Normann 2011). Isegran ville være en turistattraktion og henvende sig til fremmede turister som, til forskel fra fredrikstadboerne, ikke havde nogen særlig kundskab om byens berømte mænd.

Storytelling handler om loyalitetsskabelse. Loyalitet defineres her som gæstens genkendelse og følelse af relevans: en fortælling man kender i forvejen, som er genkendelig, husker man. I storytelling 'spinner' man på allerede kendte mediefortællinger, kulturelle diskurser og generelle meta-narrativer. Fortællingen bliver således betydningsfuld for gæsten, fordi 
74 den - af ham eller hende - knyttes til andre minder, erindringer og følelser. Loyalitet handler således om, at gæsten får muligheden for at føle sig tilknyttet virksomheden gennem en kulturelt genkendelig fortælling ( $\mathrm{Hjem}-$ dahl 2003).

Museet måtte henvende sig til turister som ikke var interesseret $\mathrm{i}$ - for dem - lokalt identitetsbyggeri. I præsentationen IKON. Fredrikstad i 1700-tallet (Normann 2011) introduceredes Fredrikstad kommunes fortruktne metode til opgaven, nemlig interpretive planning - en variant over cultural planning. Den amerikanske konsulent John Veverka var en af de første som introducerede denne planlægningsmetode til forvaltere og udviklere indenfor kulturarvsmuseerne i Skandinavien. $\mathrm{Nu}$ skulle forvaltere og udviklere af slotte, botaniske haver, museer og kulturmindepladser trænes i en "cutting edge in heritage interpretation [...]. Provoke, relate, reveal and more!", lovede konsulenten på sine kurser. Egentlig sammenfattede metoden narrative begreber som storytelling, målgruppeforståelse, samt en rangering af fortælletemaer i vigtigt og mindre vigtigt, afhængig af målgruppen. Kulturarvsformidling skulle således perspektiveres i forhold til "kundskab om publikum, markedsstrategier og markedsføring". ${ }^{2}$

Skulle man provokere, relatere og afsløre, var storytelling-begrebet anvendeligt, fordi det appellerede til 'den følende modtager'. Kulturarvsturister er primært interesseret i lokal kulturhistorie, hvis den er relateret til deres emotionelle og identitetsmæssige situation. Det bliver væsentligt ikke blot at kende sin egen historie, men også kende, kategorisere og identificere de Andres (Kjær 2011b).

Som nævnt var Tordenskjold mere 'berømt' i Google-forstand end Erlingsson den yngre. Mens Tordenskjold af de museumsansatte blev opfattet som irrelevant - det eneste han havde med Isegran at gøre, var de fire-fem sunkne krigsskibe han havde erobret fra svenskerne og fortøjret på øen. I modsætning til Erlingsson den yngres borgruin Tårnet var alle genstande, knyttet til Tordenskjold, imaginære, sunkne eller brændte - men Tordenskjold var alligevel, i markedsføringsøjemed top of mind, altså genkendelig for en udefrakommende, fordi han var stærkere repræsenteret $\mathrm{i}$ de digitale medier. Valgte man Tordenskjold som signatur og place brand, mistede man Erlingsson den yngre som grundlæggerberetning. I stedet fik man en kendis-historie med tilhørende mulighed for at lancere tematiske Tordenskjold-produkter, fortællinger og komsumptionsvarer, som allerede fandtes på markedet. Lokalmuseet forvaltede nærmest ikke autentiske, nationale genstande, som jo var i statens varetægt. Kunne rollen som museal stedsudvikler netop blive lokalmuseets fordel? Her havde fortidens symbolske og 'almindelige' materialitet en museal værdi, som ofte kunne bruges og anvendes. Man måtte naturligvis stille spørgsmålet om, hvad der kunne udvælges til brug og bevaring, samt hvordan immaterielle genstande - som Tordenskjolds sunkne og nedbrændte skibe - kunne få en historie. Hvordan kunne fortiden gestaltes og formidles, hvilke formål og funktioner skulle materialiteten have (Aronsson 2004)?

\section{OpLEVELSESBYEN}

Projektbeskrivelsen Business to Heritage (2010) ville fremme kulturmøde, diversitet og mangfoldighed. Som de fleste senmoderne byplanlæggere hyldede også Fredrikstad kommune ideen om den generøse og rummelige by.

Resultatet skulle blive en urban fritidskultur - den kultur som større byer sælger til tu- 
rister ved at have mange aktive og kreative grupper, som befolker cafeer, parker og gallerier. Den amerikanske professor i markedsføring Richard Florida (2008) og hans skrifter er vidt udbredt til de fleste kommuner, hvor byplanlæggere og kulturadministratorer søger at opnå "atmosfære", "stemning" og "vitalitet" gennem deres kulturpolitik: Det handler om at aktivere byens borgere med sundheds- og kulturaktiviteter, så de levendegør byens fritidsrum på positivt formulerede måder (Kjær 1010). Dette kulturbegreb handler om at instrumentalisere det allerede skattefinansierede kulturfelt, som museer, gallerier, teatre og koncerthuse, biblioteker samt fritids- og aktivitetstilbud.

Ved nærmere eftersyn var kommunens beskrivelse af publikum på museumsøen imidlertid defineret som den købestærke middelklasse, folk som havde råd til "båd", mennesker som tog på "konference" og "familier" formentlig med to indtægter, og ikke indvandrere, enlige mødre eller servicearbejdere. Stemningen skulle være "vital" og "attraktiv", men også "økonomisk bærekraftig”, forklarede projektbeskrivelsen. Man kan kun gisne om, hvorvidt "entreprenørerne" egentlig var studenter, og de "unge pensionister" som der stod, førtids- eller invalidepensionister, som kunne fungere som 'gratis' indholdsleverandørerer ved, i forvejen, at være offentligt forsørget.

Siden begyndelsen af 1990'erne har "borgeren" således for alvor fået status af konsument eller producent i stedsudvikling. Som de engelske sociologer Ash Amin og Stephen Graham (1997: 421) forklarer i artiklen "The Ordinary City", er tendensen i den senmoderne oplevelsesby, at de købekraftige samfundsgrupper som oftest opnår flere rettigheder og privilegier end de mindre købekraftige, som omvendt forventes at levendegøre stedet som statist, kunstner eller frivillig (Ek 2002). Privilegierne ses ikke blot i form af kulturtilbud tilpasset middelklassen (Kjær 2011b), men også i en udstødelse af underklassen - aldrig har byen haft så meget social kontrol og elektronisk overvågning som nu, mener Amin og Graham. Den spændende, humane og kulturbaserede by er ikke desto mindre det, som de fleste planlæggere og turistbureauer fokuserer på, mens de velvilligt støtter kultur- og museumsprojekter som events, festivaler og temadage. Denne type kulturkonsumption vidner om en "temporær illusion", at kulturaktiviteterne for et kort øjeblik symboliserer urban enhed. Aktiviteterne skaber en følelse af, at byen tilhører hele befolkningen, fattig som rig. Kulturaktiviteterne kan imidlertid let påpege samfundets øvrige konflikter og sædvanlige sociale forskelle, mener sociologerne.

Kulturhistorisk set var Fredrikstad by blevet en del af år 2000-tallets epoke og den "ny økonomi”, som gik under flere navne: The New Economy, The Experience Economy, The Cultural Economy. Denne type økonomi definerer de hollandske oplevelsesøkonomer Boswijk, Thijssen og Peelen (2007: 157) således, at "oplevelser, specielt indenfor turisme, oplevelses- og fritidsindustri, lægges til varer og tjenester". Metoder som iscenesættelse, konceptualisering, branding og storytelling er primære redskaber, når markedsværdien for en virksomhed, by eller region skal højnes. Målet er differentiation - niching eller anderledeshed - når fysiske omgivelser og produkter lanceres som oplevelser i konkurrencemarkedet. Men Fredrikstad kommune ønskede mere end det. Der skulle skabes "brukeropplevelser" og "formidling av kulturarv". Sågar skulle det maritime tema fungere som "oppdragende miljølæring for nye generasjoner", som projektbeskrivelsen Business to Heritage (2010) 
76 forklarede ambitionen for de museale læringsog dannelsestilbud.

På Isegran museumsø havde man således den udfordring, i praksis, at få tilgodeset forskelligartede samfundsgrupper, sådan som den politiske hensigt (næsten) havde været. Dette kunne gøres gennem et nøje tilrettelagt oplevelsesdesign.

\section{Oplevelsesdesign}

Museets nye roller som stedsudvikler havde ikke et videnskabeligt projekt som fundament. Alligevel var udstilling og formidling museets kerneområde. Det samme var design af miljøet og organisering af genstande i større sammenhænge. Fredrikstad kommune havde jo bedt om et "helhetligt opplevelseskonsept", som måske kunne minde om et frilandsmuseum, en boplads eller en slags rekonstruktion af et miljø med "etnografiske sager, sat sammen efter geografi og funktion" (Mordhorst 2009: 270).

En sådan helhedsoplevelse var ikke nogen ny forteelse. Den danske litteraturprofessor Rasmus Nyerup (1759-1859) havde en særlig interesse, nemlig at skrive rejselitteratur fra sin egen hovedstad. I Fragmenter af en Reise til Kjøbenhavn i Aaret 1837 beskrev han, hvordan han, d. 17. januar, havde været på "gjennomvandring" i det Danske Nationalmuseum: "Med hvilke Følelser man betræder dette den mørke Oldtids hellige Tempel. Hjertet banker af vemodig Glæde, naar Fortiden saaledes oprulles for vore Øjne". I de "halvhensmuldrede bøger" kunne man nok læse om "henfarne Tiders Sæder" men bogen kunne slet ikke måle sig med museets nye formidlingsteknologi. "Enkelte Mænds Gjemmer, skjult for Grandskerens og Kjenderens Øie, findes her nu samlet som som et skjønt hele", som Nyerup be- skrev det for sin læser (efter Mordhorst 2009: 276).

Også på Isegrans fremtidige museumsø skulle gemmerne løftes frem til et skønt hele. De engelske turismeforskere Gareth Shaw og Allan M. Williams (2004: 244, min oversættelse) definererer et "oplevelsesdesign" således:

Et oplevelsesdesign er et materielt opbygget og totalt miljø. Måden miljøet bliver totalt på går via dets velgennemtænkthed og planlægning. Miljøet er velkoreograferet, nøje opbygget, kulturelt tematiseret, men også et ekstremt regulerende sted: Det kulturelt tematiserede miljø regulerer kroppene i den forstand at det 'bestemmer' hvilke følelser, tanker, normer, moralset og sociale relationer der er mulige og ikke-mulige, at opleve præcis på dette sted.

Hensigten med at skabe et totalt miljø - som man således kender fra temamuseet, temaparken, shoppingcenteret, badelandet, skisportstedet eller hotellet - handler også om, at genstande af varierende kvalitet og beskaffenhed tilsammen kan referere til en meningsfuld metanarrativ. Det handler om at styre og føre gæstens sensoriske oplevelser via æstetiske og designrelaterede greb (Strömberg 2009).

Et oplevelsesdesign har til hensigt at transformere nedslidte og forladte steder til rekreative områder. Men ambitionen er også til fulde, at udnytte kulturarvsattraktionens potentiale i en bredere konkurrencemæssig sammenhæng. Et kommunalt og musealt oplevelsestilbud bør kunne vinde gæstens opmærksomhed på lige fod med et kommercielt tilbud. For at vinde andele $\mathrm{i}$ fritids- og turismemarkedet er oplevelsesinnovation og forståelse af oplevelseskonsumenten vigtige metoder.

En turist er sjældent interesseret i kommunegrænser. Man skelner ikke mellem kom- 
mercielle og ideelle, statslige og kommunale attraktioner, men fokuserer på at ønsker og behov realiseres så uproblematisk som muligt. Som udvikler bør man gøre sig klart, at gæsten sammenligner alle attraktioner, uanset at de investerede kræfter og midler varierer. Gæsten er kundskabsrig og har stor erfaring med oplevelsestilbud - både gennem rejser og medier, og han eller hun forventer det enkelt, nemt og skræddersyet. Endelig har stedets vilkår, de lokale omgivelsers infrastruktur, transport og tilgængelighed, hoteller, service og gæstfrihed, ligeså stor betydning for en kommunal attraktions popularitet som de har for en kommerciel.

Den tematiske - eller konceptuelle - æstetisering af oplevelsesdesignet har til hensigt at regulere et publikum, således at man får en sansningsoplevelse, der er rettet mod en bestemt type læring. Boswijk, Thijssen og Peelen (2007: 145-146) forklarer, at de fleste managementbøger i turistbranchen nøjes med at hævde, at oplevelsen af en attraktion bør være "mindeværdig". Som udviklingsstrategi betyder det i praksis at eliminere negative elementer $\mathrm{i}$ attraktion. Moralisering og forbud på skiltning, skræmmende historier om samfundets sociale og miljømæssige tilstand eller kulturmøder som forventes at være ubehagelige og friktionsfyldte, reduceres i det omfang det er lovgivningsmæssigt muligt. Dette har imidlertid ofte den konsekvens, at selve oplevelsesproduktets læringspotentiale også udtømmes. Oplevelsen må ikke udfordre, stille krav eller provokere ligesom eksempelvis kunst må. Derfor kan oplevelsesproduktet også blive mindre meningsfuld, menneskeligt irrelevant eller bare tamt (Kjær 2011b). Udfordringen hos kommunens og museets administratorer som netop har et ideelt samfundsansvar - bliver at tillade sig, at levere kulturoplevelser som rummer en høj grad af kompleksitet, samtale og eksistentiel mening.

Tematisering er en mulighed for at skabe helhed i et miljø. Man er interesseret $i$ at stimulere al sansning - lugt, smag, syns, høre og følesans - i en bestemt tematisk retning, således at man oplever atmosfæren af "det maritime" - stemningen af et maritimt sted. Ligesom i storytelling er abstraktioner mere væsentlige end det konkrete, og ligesom litteraturprofessor Nyerups følelsesmæssige højtstemthed, skal oplevelsesdesignet lægge til rette for den "sjette sans", som - hvis man spurgte en magiker - ville definere som en syntese af de fem sanser, hvorfra det hele fusioneres til en ekstraordinær oplevelse. Oplevelsesdesigneren skal således forestille sig, hvordan denne følelsesmagi nærmest fungerer som et ritual af sansning, mening og forestilling der, tilsammen, skaber en "absorberende totaloplevelse" for gæsten (O’Dell 2006).

\section{FRIKTIONSFRI FRITID}

Projektplanen for Isegrans fremtidige museumsø lød som en absorberende oplevelsesverden, hvor (næsten) alle befolkningsgrupper skulle tilfredsstilles, deltage og bidrage. Denne ambition var måske mere et politisk ideal, en romantisk kommunal forestilling, end en fritidskommerciel virkelighed. Hvis den senmoderne oplevelsesby var blevet kommerciel, ligesom titlen Business to Heritage (2010) indikerede, måtte vel også en kommune og et museum tage højde for markedsanalysernes konklusion, at det burde være behageligt, enkelt og bekvemt at være fritids- og kulturkonsument. Sagt på en anden måde: kulturmøde, integration og mangfoldighed var ikke noget, man nødvendigvis ønskede at betale for i sin fritid. 
Det forklarer i al fald den svenske markedsøkonom Lena Mossberg (2007: 144-145) med kundeundersøgelser indenfor service- og turismesektoren. Gæsten ønsker ikke et udfordrende kulturmøde med andre i sin fritid med mindre det er hele formålet med oplevelsen, sådan som idealet er i backpacker, eventyr- og oplevelsesturisme. Tværtimod er gæstens primære interesse at skabe relation mellem sig selv, genstande og (kommercielle) produkter. Individet er motiveret af at få sine mest avancerede behov som følelsesudvikling, relationsbyggeri og personlig udvikling aktiveret af attraktionens oplevelser. Tilfredsstillelsen af individets avancerede behov er - eller bør være - hovedformålet, mener Mossberg. Ideelle attraktioner - kommunale og statslige museer, parker, fritids- og aktivitetsområder bør være af så høj kvalitet og have et så relevant meningsfuldt indhold, at publikum, selvom indgangen er gratis, ville være villige til at betale entré, istemmer også Boswijk, Thijssen og Peelen (2007).

Lena Mossberg forklarer, at kunden ønsker det enkelt og nemt. Han eller hun vil være sammen med ligesindede. I servicemarketingteorier, f.eks. indenfor brancher som hotel, restaurant eller turistattraktioner, skaber det således værdi for gæsten, hvis man anvender compatibility management - dvs. håndterer forskellige sociale grupper på forskellig vis, ikke sammenblander grupper som har forskellige type identitet og som - kulturelt set - opfattes som i konflikt med hinanden. Målet er at tilrettelægge service, omgivelser og miljø samt "kunde-til-kunde møder", for at minimere utilfredsstillende møder. Customizing forklarer Mossberg - er en anden term for det friktionsfrie og enkle fritidsliv som gæster ønsker, når de selv skal betale for en fritids- og kulturaktivitet. Her skræddersys oplevelser, produkter og omgivelser til hver enkelt kundegruppe, således at hver gruppes kulturelle behov for mening og identitetsbekræftelse tilfredsstilles. Målet er naturligvis at skabe tilfredse kunder. En tilfreds kunde er også en loyal kunde, som gerne videreformidler den bedste reklame en virksomhed kan få, nemlig det gode rygte (Mossberg 2007).

Man kan indvende at kulturarvsindustri, museer og stedsudvikling ikke lægger til rette for 'kunder', men for publikum, museumsgæster og borgere. Man kan også hævde, at en kommunes og et museums fornemste opgave er at tilbyde læring til alle samfundsgrupper, således at samfundet dannes og deraf - er forestillingen - bliver harmonisk og tolerant.

En vigtig forudsætning for et oplevelsesdesign må - ud over tematiseringen - handle om, hvordan forskellige befolkningsgrupper og deres sociale organisering former forestillinger, stereotypier og fordomme overfor andre sociale grupper. Dette har betydning for, hvordan gæsterne ville interagere med hinanden på den specifikke plads.

\section{OpleVELSESGEOGRAFI}

Vender man tilbage til projektbeskrivelsen $\mathrm{Bu}$ siness to Heritage (2010) havde man ikke nødvendigvis nogen socio-kulturel forklaring på, hvad det ville sige at placere "unge barnefamilier" og "konferansemarkedet" sammen i Isegrans oplevelsesgeografi. Andre publikumsog befolkningsgrupper - ud over bådfolket var, som sagt, ikke nævnt. Eksemplet kan alligevel undersøges med kulturanalytisk kundskab om, og deltagerobservation over rutiner, vaner og adfærd. De nævnte gruppers hverdagskultur var ganske forskellige: børnefamilier er primært, men ikke kun, optaget af legepladser, madpakkefaciliteter, samt trygge og 
overskuelige omgivelser med ligesindede børnegrupper. Konferencegæster er primært, men ikke kun, optaget af effektiv infrastruktur, mødelokaler, (dyre) restauranter med service, ligesindede voksne, bekvem hotelservicefunktion såsom vask og strygning, internet, avis og morgenmad. Begge grupper er interesseret $i$ infrastruktur, selvom tempoet $\mathrm{i}$ at komme fra A til B sikkert betyder mere for forretningsfolk end for børnefamilier (se også Ehn \& Löfgren 2001/2006).

En sådan (stereotyp) identifikation af forskellige sociale grupper fremmer forståelsen af, at sociale gruppers forskelligartede adfærd, værdier og normer naturligvis har betydning for konkretiseringen af et oplevelsesdesign. Sameksistensen mellem disse grupper bør vel fungere mere harmonisk end tålt?

Udover at, ideelt set, præsentere en bevidst konstruktion af materialitetens meningsfuldhed, hvor genstande, geografi, rum og plads, tematiseres og æstetiseres med kulturhistoriske fortællinger og udstillinger, bør et oplevelsesdesign således også inkludere en forståelse af, hvordan forskellige sociale grupper på forhånd motiveres til at anvende oplevelsesrum på baggrund af deres sociale omgangsformer, ritualer og aktiviteter, såsom leg, læring, oplevelse, afslapning, bevægelse og konsumption.

Hvordan hver enkelt gruppe ønsker at blive forstået er dermed vigtigt (Boswijk, Thijssen og Peelen 2007: 145-146). Jo mere velgennemtænkt oplevelsesdesignet er, desto bedre anvises de sociale regler non-verbalt ved hjælp af materialiteten.

På Isegran kunne oplevelsesgeografien strategisk designes således, at æstetisering, belysning, lydsætning og beplantning eksempelvis ville skabe tryghed og afskærming. Forskellige områder kunne også markeres, så det var enklere at finde rundt. Infrastruktur, gangsyste- mer og udforming kunne ydermere indikere, hvilken aktivitet et enkelt rum skulle bruges til, og dermed også - indirekte - anvise hvem det var tiltænkt. På den måde kunne man funktionsbestemme og helhedsdesigne oplevelsesrum, samtidig som man kunne tage højde for potentielle konflikter, når forskellige sociale grupper skulle leve side om side.

Et oplevelsesdesign er manipulerende i den forstand, at det har til hensigt at "regulere kroppe" og "bestemme, hvilke følelser, tanker og sociale relationer" der er mulige at opleve, forklarer humangeograferne Gareth Shaw og Allan Williams (2004). I kulturhistorisk perspektiv er denne regulering dog hverken noget nyt eller noget dårligt. 1800-tallets epokegørende oplevelsesmatrice, nemlig den romantiske landskabshave (the romantic English garden), havde til hensigt at aktivere følelse, sansning og oplevelse. I en nøje planlagt og optisk konstrueret 'utæmmet' natur, kunne publikum bevæge sig fra overraskelse til overraskelse. Bag hvert hjørne opstod et nyt perspektiv, som fik haven til at synes som et uspoleret og naturligt landskab.

Landskabshaven var, set med vor tids tematiseringslogik, en underlig hybrid, men faktisk var dens orden defineret som et eksotisk kammer - fyldt med materialiteter som skulle forestille at tilhøre forskellige kulturer, materialegrupper og geografier. Det var netop oplevelsen af eksotisk rigdom, at kunne rejse i sin egen (kongelige) baghave, som var formålet. Selvom landskabshaven egentlig bestod af kulisser, var den opfundet til at skærpe sansningen. Over hele Nordeuropa blev havedesignet med sine slyngede stier og floder, små øer og vilde skovanlæg moderne. Sceneri, overraskelser og miljø var næsten ligeså standardiserede som vor tids temaparker.

Sansningsteknologierne var nøje tilrettelagt. 
80 Planter duftede og vandfald bruste. I den eksotiske hybrid kunne man overraskes af græske templer, kinesiske lysthuse, eremitgrotter, norskehytter, antikke skulpturer og gravhøje (Löfgren 2002: 21-26).

Op til idag har landskabshaven formået at inspirere alt fra offentlige byparker til kommercielle temaparker. Gennem flere hundrede år har designet langsomt men sikkert 'sat sig fast' i nordeuropæerne kropslige oplevelseshabitus. I al fald er ekstraordnære oplevelse, baseret på helhedssansning, i totale miljøer ikke gået af mode. Formen idealiserer nok de højstemte følelser af begejstring. Havens grundstruktur med kontrollerede overraskelser og bevægelsessystemer er fortsat anvendelig som en matrice for et oplevelsesdesign, der både handler om bevægelse, hvilepunkter og oplevelsesaktivitet.

\section{KONKLUSION}

I de senere år har lokalmuseet fået en ny rolle som stedsudvikler. Som byens identitetsskaber forestiller man sig kultur i bred forstand har en ekstraordinær kraft, som kan æstetisere, udvikle og designe 'den almindelige by', således at indbyggere oplever stolthed og nytilkomne får lyst til at bosætte sig.

Udviklingen af en maritim stedsidentitet på Isegran skulle både inkludere kulturarvsmuseum, en turistattraktion, et bydels- og fritidsområde for byens beboere. Ambitionen var politisk styret og påvirkede projektets tematiske indhold - at det skulle handle om maritim kulturarv, søhelte og en forvaltning af fraværende originalgenstande. På den måde var flere kulturbegreber i spil - nemlig hverdagskulturen, præsenteret gennem forskellige samfundsgruppers dagligliv, normer og værdier; den institutionelle dannelseskultur, præ- senteret gennem museets formålsparagraffer om oplysning og, endelig, kommunens kommercielle værdiskabningsideal der handlede om, hvordan den lokale kulturhistorie kunne anvendes som planlægningsredskab for at skabe atttraktive urbane områder og fritidsaktiviteter. Hvis det urbane oplevelsesdesign skulle være demokratisk, måtte det imidlertid erkendes, at sociale grupper har forskellige hverdagskulturer, social organiseringer, normer og præferencer. For at opnå idealet om den harmoniske by, måtte hvert oplevelsesområde på øen planlægges, således at de enkelte gruppers identitet blev imødekommet.

Den kulturelle indholdsproduktion, men også stedsdesignet, påhvilede på museets. Man var ansvarlig for, at den maritime metanarrativ fungerede således, at oplevelsen spontant kunne associeres til en sensorisk, symbolsk og tematisk helhed over "det maritime”. Med æstetiske og designrelatede greb kunne museet anvende fortiden til at skabe en oplevelsesgeografi, en stedsidentitet og en samfundsdokumentation. Gennem kontekstualisering storytelling, levendegørelse og iscenesættelse kunne alle typer genstande, også de forhåndenværende, 'almindelige' og ikke pladsrelaterede, opnå en museal værdi.

\section{NOTER}

1. Business to Heritage - B2H. Interregionalt projekt Sverige-Norge. Projektansökan/Søknad projektutlysning, 9-2010.

2. http://www.heritageinterp.com/whatis.htm (2012.10.16) 


\section{REFERENCER}

Amin, Ash \& Graham, Stephen: "The Ordinary City". Transactions of the Institute of British Geographers, vol. 22, no. 4, 1997: 411-429.

Bosjwijk, Albert, Thijssen, Thomas \& Peelen, Ed: The Experience Economy. A New Perspective. Pearson Education Benelux: Amsterdam 2007.

Becker, Annesofie: "Museets ting og udstillingens orden". Tidsskriftet Antropologi. Nr. 21/22, 1990: 69-80.

Ehn, Billy \& Löfgren, Orvar: Kulturanalyser. Forlaget Klim: København 2001/2006.

Ek, Richard: "Vi skal iscenesætte vores by". I: Tom O’Dell (red.), Upplevelsens materialitet. Studentlitteratur: Lund 2002, 127-149.

Eriksen, Anne: "Bygda vår - fra bygdebøkenes verden". I: Anne Eriksen, Jan Garnert, \& Torunn, Selberg (red.), Historien in på livet. Diskussioner om kulturarv och minnespolitik. Nordic Academic Press: Oslo 2002, 195-216.

Evans, Graeme: Cultural Planning. An Urban Renaissance. Routledge: London 2001.

Florida, Richard: "How Cities Renew". Monocle. Issue 15, vol. 02, July/August 2008: 59.

Aronsson, Lars, Bjälesjö, Jonas \& Johansson, Susanne (red.): Kulturell ekonomi. Skapandet av värden, platser och identiteter i upplevelsesambället. Studentlitteratur: Lund 2007.

Aronsson, Peter: Historiebruk: att använda det förflutna. Studentlitteratur: Lund 2004.

Hall, Stuart \& Whannel, Paddy: The Popular Arts. Hutchinson Educational: London 1964.

Hjemdahl, Kirsti Mathiesen: Tur-retur temapark. Oppdragelse, opplevelser, kommers. Høyskoleforlaget: Kristiansand 2003.

Johansen, Erling et al.: De annalibus Isegrani. Hendt på Isegran 1287-1997. Universitetets Arkeologiske Stasjon Isegran: Oslo 1999.

Kayser Nielsen, Niels: Historiens forvandlinger. Histo- riebrug fra monumenter til oplevelsesøkonomi.

Aarhus Universitetsforlag: Århus 2009.

Kjær, Sarah Holst: "Den emotionelle storby". I: Jahn Thon \& Roy Eriksen (red.), Hvem eier byen? Tekst, plan og historie. Novus Forlag: Oslo 2010, 127-141.

- "Designing a Waterworld. Culture-Based Innovation and Ethnography in Regional Experience Industry". Ethnologia Europea. Journal of European Ethnology. Vol. 41:1, 2011 a: 81-95.

- "Kystturisme, fyrtårne og romantisk oplevelsesdesign. It's Lovely Here!" Kulturella PerspektivSvensk etnologisk tidskrift. Nr. 2, årgang 20, 2011b: 21-32.

Löfgren, Orvar: On Holiday. A History of Vacationing. University of California Press: Berkeley 2002.

Mordhorst, Camilla: Genstandsfortallinger. Fra museum Wormianum til de moderne museer. Museum Tusculanums Forlag: København 2009.

Mossberg, Lena: A skape opplevelser: Fra OK til WOW! Fakbokforlaget: Bergen 2007.

Nielsen, Arno Victor: "Indledning". Den jyske historiker. Museum Europa. Nr. 64/juni, 1993: 5-10.

Normann, Steinar: "IKON. Fredrikstad i 1700. Forskningsresultater (foreløpig). Februar”. Østfoldforskning 2011.

O’Dell, Tom (red.): "Upplevelsens lockelser, tingens dynamik", Upplevelsens materialitet. Studentlitteratur: Lund 2002, 11-34.

- "Meditation, Magic and the Spiritual Regeneration: Spas and the Mass Production of Serenity". I: Orvar Löfgren \& Robert Willim (red.), Magic, Culture and the New Economy. Berg: New York 2006, 19-36.

von Plessen, Marie-Louise: "Af kærlighed til tingene". Den jyske historiker. Museum Europa. Nr. 64/juni, 1993: 127-133.

Ronström, Owe: Kulturarvspolitik. Visby. Från sliten småstad till medeltidsikon. Carlssons Bokförlag: Stockholm 2007. 
SARAH HOLST KJaER

82 Shaw, Gareth \& Williams, Allan: Tourism and

Tourism Spaces. Sage: London 2004.

Strömberg, Per: "Destinationsdesign - förstärkta fjällupplevelser". Arkitektur 3, 2009:14-19.

Thufvesson, Ola: Platsutveckling. Lunds universitetet, Campus Helsingborg, skriftserie 1/09, 2009.

*Sarah Holst Kjer, fil. dr, senior researcher

Adresse: Agder Research

Department of Culture Industries

Gimlemoen 19

NO-4630 Kristiansand, Norge

E-mail: Sarah.Holst.Kjar@agderforskning.no 